Materials \& Design

March 2016, Volume 94, Pages 207-213

http://dx.doi.org/10.1016/i.matdes.2016.01.011

http://archimer.ifremer.fr/doc/00307/41800/

(c) 2016 Elsevier Ltd. All rights reserved.

\title{
Flax/PP manufacture by automated fibre placement (AFP)
}

\author{
Baley Christophe ${ }^{1}$, Kervoelen Antoine ${ }^{1}$, Lan Marine ${ }^{1}$, Cartié Denis ${ }^{2}$, Le Duigou Antoine ${ }^{1}$, \\ Bourmaud Alain ${ }^{1}$, Davies Peter ${ }^{3, *}$
}

${ }^{1}$ University of South Brittany, LIMATB, Rue de Saint Maudé, 56000 Lorient, France

${ }^{2}$ Coriolis Composites SAS, Rue Condorcet, Z.A. du Mourillon, 56350 Quéven, France

${ }^{3}$ Ifremer, Centre Bretagne, Technopôle Brest Iroise, 29280 Plouzané, France

*Corresponding author : Peter Davies, email address : peter.davies@ifremer.fr

\begin{abstract}
:
Automated fibre placement (AFP) has been used to manufacture flax/polypropylene biocomposites for the first time. This required preparation of tape with a calibrated width from impregnated fibre sheets. The unidirectional tapes showed polymer-rich zones on the surface. During manufacture the polypropylene (PP) is melted locally with a laser. A consolidation step in a hot press is then required to reduce void content. The flax fibres, composed of polysaccharides, have limited thermal resistance so optimization of the thermal cycle is necessary, but subsequent characterization of mechanical behaviour showed no evidence of property loss in spite of an additional melting cycle. AFP appears to be a promising manufacturing method for biocomposites.
\end{abstract}

\section{Graphical abstract}

\section{Calendered Flax/PP Tape}

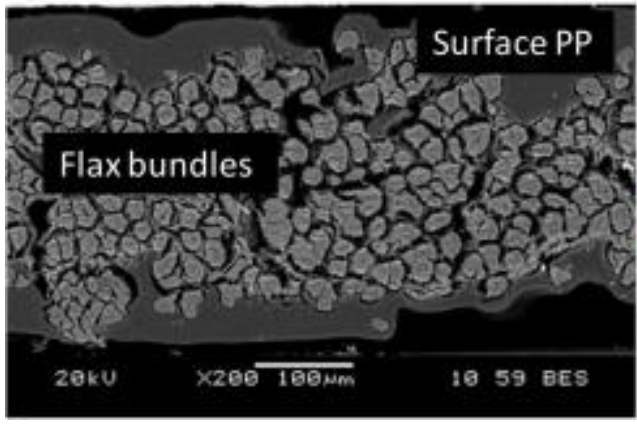

AFP composite

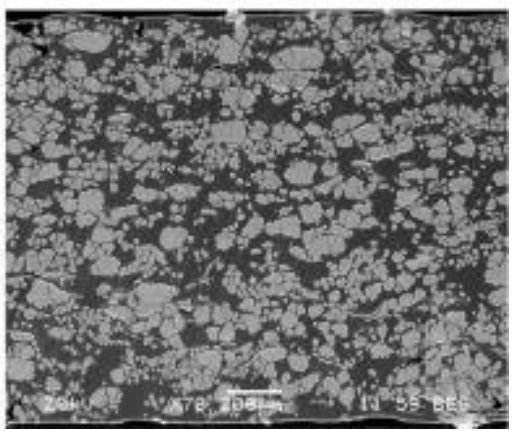




\section{Highlights}

- A new process to produce flax/PP tape for AFP is described, using calendering between rollers. Microstructure analysis shows surface polymer and good impregnation. AFP forming process allows manufacture of temperature sensitive natural fibres. Mechanical properties comparable to those for compression moulded plate specimens.

Keywords : Structural composites, AFP, Biocomposites, Flax, PP 


\section{Introduction}

In order to use composites in structural applications it is preferable to reinforce them with continuous fibres. For large structures thermoset matrix resins are generally used, but there is increasing interest in thermoplastics. For example, these materials have been used in bus bodywork [1], boat hulls [2], and lorry trailers [3].

The major benefits in processing thermoplastic composites compared to thermoset composites are the unlimited shelf life, the short processing time, low human toxicity during the process, and their ability to be re-melted and reprocessed. No time is required for chemical reactions to occur during processing, in contrast to the case of a thermoset. Thermoplastics have also the ability to be processed at various heating and cooling rates in thick sections, due to the absence of the exotherm experienced in the case of thermosets. The capability of thermoplastics to be remelted has led to the development of novel manufacturing and repair technologies. For example: post forming operations and assembly or repair by local welding $[4,5]$. Thermoplastic laminates showing voids or defects can be reconsolidated to eliminate these defects whereas a thermoset would be rejected [6-8]. In the auto-consolidation process, only the area that is being immediately consolidated is heated above the melt temperature, the remainder of the part is held at temperatures well below the melt temperature. Heating is frequently applied by a focused laser beam at the nip point, other forms of heating include hot gas torches, quartz lamps and infrared heaters. The fact that auto-consolidation is possible implies that the contact times for many thermoplastic polymers can be quite short. Provided sufficient contact pressure is applied at the ply interfaces, auto-consolidation can occur in less than $0.5 \mathrm{~s}[6,9]$.

A potential problem with auto-consolidation is lack of consolidation due to insufficient diffusion time. If a well-impregnated prepreg is used, then only the ply interfaces need be consolidated. However, if there are intraply voids, then the process time is so short that there is insufficient time to heal and consolidate these voids and a post-consolidation cycle will be 
required to achieve full consolidation [10]. It should also be noted that while repair is often cited as an advantage for thermoplastic composites, the real potential is limited when part geometry is complex due to the need for an appropriate supporting mould to avoid distortion. Thermoset composites can also be repaired, though this often requires the use of patches and involves cutting the fibre reinforcements. Finally, at the end of their service life thermoplastic composites can be recycled to some extent. Currently this tends to involve mechanical grinding and re-using the material for injection moulding.

The main drawbacks with processing thermoplastics compared to processing thermosets are their high melt viscosity and, for high performance polymers, the high processing temperatures needed to melt them. The time required to reach consolidation temperature is a function of the heating method since time for chemical reactions is not required. The consolidation temperature depends on the specific thermoplastic resin, but should be above the glass transition temperature $\left(\mathrm{T}_{\mathrm{g}}\right)$ for amorphous resins or above the melt temperature $\left(\mathrm{T}_{\mathrm{m}}\right)$ for semi-crystalline materials. The time at temperature required for consolidation is primarily a function of the product form used [6].

At such high temperatures, depending on the thermal stability of the polymer which may vary significantly from one polymer to another, thermal and oxidative degradation may occur.

The reinforcement of polymers with flax fibres can be justified based on their unique properties (low density, renewable resource, good mechanical properties and low environmental impact) [11]. Natural fibres are discontinuous by nature, but among the various fibres available elementary flax is relatively long (from 10 to $100 \mathrm{~mm}$ ). Some recent studies have started to examine the use of flax fibres to reinforce large structures such as wind turbine blades $[12,13]$.

Various polymers are available to use as a matrix, but polypropylenes (PP), are particularly attractive as they enable recyclable bio-composites to be obtained [14]. These have several 
advantages, including low cost, good mechanical properties and a manufacturing temperature which is sufficiently low to be compatible with avoiding damage to the fibre cell walls.

However, in spite of all these advantages, PP can show structural changes during processing and in particular oxidation degradation $[15,16]$. This sensitivity is more marked at the start of the process, when contact with air can lead to the creation of free radicals and partial depolymerization; this phenomenon explains the limited stability of PP during recycling.

To produce composite materials, processes such as AFP (Automated Fibre Placement) have been developed, which allow the optimization of reinforcement lay-up, close control of process parameters [17] and minimize the number of defects. An automated fibre placement machine applies tows (of $3.175 \mathrm{~mm}$ to $12.7 \mathrm{~mm}$ width), in the form of a ribbon of unidirectional prepreg with fibres in either thermosetting or thermoplastic matrix but also powder tows for RTM, onto the surface of a mould through a placement head. This technique enables complex geometries to be produced. In order to obtain the required dimensions the tape placement is optimized, controlling the orientations and lengths of the tapes to limit defects (gaps and overlaps). When defects do occur in carbon/epoxy parts the use of a caul plate during autoclave cure can help to heal them, so that their influence on mechanical properties is limited [18].

In order to manufacture composites reinforced by long fibres and impregnated with a thermoplastic matrix, different semi-products have been developed, such as co-woven yarns, inter-dispersed fabrics, plied matrix, powder impregnation and commingled materials, for which impregnation occurs during final forming [19]. The AFP process requires preimpregnated tapes, as the material is heated locally. The lack of tack and drape of most thermoplastic prepregs is a drawback.

For aeronautical applications there has been considerable development of carbon fibre reinforced high performance thermoplastics. The latter show high melting temperatures, such 
as PEEK (polyetheretherketone) [20-22]. Robots have therefore been adapted to the process, and different heating techniques have been developed [23]. The use of a laser is often considered to be the most appropriate heating method (high energy density, efficiency and rapid response time). The general concept is that melt bonding of polymer surfaces involves three stages: intimate contact, molecular diffusion (reptation or auto-adhesion) and consolidation [23]. A laser enables the heated zone to be closely controlled and the polymer to be melted just before placing the tape and compacting with a roller. In general, after tape layup by AFP components are consolidated in an autoclave to minimize defects.

The high temperature thermoplastic polymers used in aeronautical structures are not suited to AFP with natural fibres. The flax fibre cell walls are mainly composed of oriented cellulose micro-fibrils held together by a polysaccharide matrix. Among these constituents, Gorshkova and Morvan [24] have shown that it is the galactanes which play an essential role in the rigidity of the fibres. Given the sensitivity of these polymers to the temperature, both structural and biochemical degradation of the cell walls can be expected for thermal cycles above $100^{\circ} \mathrm{C}$. Gassan et al. defined a maximum forming temperature for flax fibres of $170^{\circ} \mathrm{C}$ [25]. Gourier et al. [26] have shown that stiffness and strengths are changed after thermal cycles. This is observed above $200^{\circ} \mathrm{C}$ for one short cycle, but also at $105^{\circ} \mathrm{C}$ after a 14 hour cycle, indicating the importance of the time-temperature relationship.

At the cell wall level, the influence of process time on mechanical behaviour was shown by nano-indentation, using different compounding times [27]. Le Duc [28] also revealed structural modifications to flax fibres after thermal cycling.

This paper is devoted to a study aimed at developing Flax/PP biocomposites for AFP manufacturing. This technique, generally applied to high performance composites, has been used for the first time to make biocomposite components. After a first phase to obtain satisfactory impregnated tapes and optimize the process parameters, flax-PP plates have been 
laid up from unidirectional tape. These were then hot consolidated in a press to reduce porosity. The influence of the number of thermal cycles on mechanical properties was studied through a comparison between composites produced from the same tape by AFP + compression (three thermal cycles) and by compression in a press alone (two thermal cycles).

\section{2-Materials and methods}

\subsection{Materials:}

The polymer used in this study was PPC Total 76421, MFI 16, with a modulus and break stress of 1600 and $27 \mathrm{MPa}$. This is an unmodified PP, without coupling agent.

Flax fibres were obtained by first dew retting the plants, then the flax stems were scutched and combed but not drawn. After combing, layers of unidirectional fibres were obtained with an areal weight of $80 \mathrm{~g} / \mathrm{m}^{2}$. No surface treatment was applied to the fibres in this study.

In order to use AFP it is essential to have a tape with closely controlled geometry, in particular the width, as eight $6.35 \mathrm{~mm}$ wide tapes are placed at the same time. The mechanical strength of the tapes must also be sufficiently high to avoid breakage. The use of twisted flax fibres is not recommended, as they are difficult to impregnate and the torsion operation alters the mechanical properties of the fibres $[29,30]$.

The production of a preimpregnated flax/PP tape suitable for AFP was only achieved after several tests using different techniques, two will be presented briefly here.

First, trial tapes were made using an extruder. However, their width was not uniform (varying between 6 and $4.8 \mathrm{~mm}$ ), the surface was very irregular and the quality of the impregnation was poor, with unimpregnated fibres apparent on the tape surface (Figure 1). The presence of these fibres on the tape surface is not acceptable, as the laser will burn them during the AFP process. 
The technique which finally produced satisfactory tapes was calendering. Hackled aligned flax fibres were calendered at temperature between two PP films (300mm width) to produce unidirectional preimpregnated bands. This technique ensures good control of the fibre alignment. The average surface weight is $153 \mathrm{~g} / \mathrm{m}^{2}$ (a theoretical fibre weight content of $50 \%$ ) and the semi-product thickness is $0.32 \mathrm{~mm}$.

These bands were either used directly in a press to produce reference panels by compression moulding, or cut into $6.35 \mathrm{~mm}$ wide tapes for transformation by AFP. After laying up by AFP plates were also compression moulded, under the same conditions as the reference materials.

Cutting of $300 \mathrm{~mm}$ wide bands into spooled $6.35 \mathrm{~mm}$ wide tapes for AFP was performed by OMEGA SYSTEMS (Nantes, France) using a proprietary slitting system.

\section{$\underline{2.2 \text { Automated Fibre Placement processing }}$}

The AFP plates were laid up using the Coriolis Composites fibre placement machine installed in the Compositic research centre at the University of South Brittany (France).

This machine is composed of an ABB IRB6600 axis robot mounted on an 8 meter linear axis. The layup head used is an $8 \mathrm{x} 6.35 \mathrm{~mm}$ tow head (maximum band width of $50.8 \mathrm{~mm}$ ). The compaction is performed by a polymeric mono-block roller (Figure 2). For a standard compaction force of $500 \mathrm{~N}$, the contact surface of the roller is approximately $55 \mathrm{~mm} \times 15 \mathrm{~mm}$. Therefore the average contact pressure applied is around $0.6 \mathrm{MPa}$ i.e 6 bars, which is lower than the press compaction pressure with heating platens (20 bars). This pressure is limited by the stiffness of the robot. The compacting process is controlled by measuring the force at the roller supports, as the roller deformation makes pressure calculation difficult. Coriolis has performed tests to study the roller crushing behaviour, in order to be able to estimate pressure from the force, but the real pressure profile is very difficult to obtain, particularly on parts with complex geometries. 
The programming of the panel was performed using the Coriolis CADFiber software V1.6. A $0.5 \mathrm{~mm}$ gap was programmed between courses in order to avoid an overlap between tapes. This value has been defined by aircraft manufacturers [18]. A staggering of $22.2 \mathrm{~mm}(3.5 \mathrm{x}$ $1 / 4$ ') was used between the plies in order to avoid superposition of the inter-tape gaps.

The heat source for processing thermoplastic composites is a 6kW LDF6000-100 diode laser manufactured by LASERLINE GmbH. The wave length of the laser ranges from 980nm to 1070nm. The optical lens mounted on the head generates a relatively homogeneous spot which is $56 \mathrm{~mm}$ wide and $8 \mathrm{~mm}$ high. After several preliminary trials for the calibration of the laser power as a function of speed, the AFP processing parameters were kept constant at the following values for the manufacture of the panels: The layup speed was $0.2 \mathrm{~m} / \mathrm{s}$, the compaction force was $500 \mathrm{~N}$ and the laser power was set at $2000 \mathrm{~W}$.

The first ply was tacked by the machine on a 25 microns polyimide film (Kapton®). The temperature was measured using an Optrix IP450 IR camera. The temperature measured by the IR camera ranged from $170^{\circ} \mathrm{C}$ to $200^{\circ} \mathrm{C}$. However, it is important to note that the emissivity of the material was not calibrated and the angle of incidence of the camera to the surface is shallow. Therefore the accuracy of the temperature measurement is questionable. The estimated temperature reached during layup is close to $200^{\circ} \mathrm{C}$.

\subsection{Press compression moulding}

Compression moulding conditions for all samples described here were heating for 4 minutes at $190^{\circ} \mathrm{C}$, then 20 bars pressure at $190^{\circ} \mathrm{C}$, then cooling under pressure (from $190^{\circ} \mathrm{C}$ to $20^{\circ} \mathrm{C}$ in 7 minutes).This cycle was fixed after several trials with varying temperatures and times under pressure followed by microstructural analyses (quality of impregnation, porosities), and is the cycle which gave the best results for both types of plate. The fibre content and plate thickness 
were controlled by calibrated metallic inserts. Differences in thermal expansion coefficients between composite and inserts will cause composite shrinkage during cooling and affect applied pressure, but final plate thicknesses were identical for both AFP and hot press composites, around $1.3 \mathrm{~mm}$.

\subsection{Stacking sequences and mechanical tests}

Plates of dimensions $700 \mathrm{~mm}$ by $370 \mathrm{~mm}$ composed of 10 plies were produced, either by AFP then compression or directly by compression moulding. These were :

- Only unidirectional plies at $0^{\circ}$ for longitudinal and transverse tensile properties. The former are highly dependent on the fibres, the latter on the matrix and fibre/matrix interfaces.

- Plies at $\pm 45^{\circ}$ to test in tension to determine in-plane shear properties according to ASTM D 3518. Shear strength was determined for a shear strain of 5\%, according to the standard. Figure 3 shows the lay-up.

\subsection{SEM observations :}

Processed samples were embedded in an epoxy resin before polishing. They were then metallized with gold before being observed through a JEOL JSM 6460LV scanning electron microscope. A morphological analysis, using Image ${ }^{\mathrm{TM}}$ image analysis software, was then carried out to study the composite microstructure, to analyze the porosity content and calculate the fibre volume fraction. Nine samples in the composite thickness were analyzed to determine each property.

\section{3-Results and Interpretation}

\subsection{Analysis of the tape cross-section after calendaring}


The aim of the calendering operation is to obtain a preform tape with a controlled fibre content, and with polymer-rich surfaces (Figure 4) which will allow easy processing.

Figure 4 shows that there is not complete impregnation and that the tape surface is irregular. This is due to the low pressure applied during calendering.

Polishing of the section, in order to examine the microstructure, has caused the fibre bundles to separate. The outer surfaces are polymer-rich, which will be favorable for AFP in order to bond successive tapes together.

\section{$\underline{3.2 \text { Analysis of sections of plates laid up by AFP and compression moulding }}$}

Figure 5 shows the microstructure of a stack of plies draped by AFP. Each ply can be distinguished with a PP-rich layer between them.

There are still porosities at the centre of the plies, this is an impregnation defect which was present after calendaring and which has only been partially reduced during AFP lay-up as the pressure and melt time are quite low (about $0.6 \mathrm{MPa}$ or 6 bars). The tension in the tape varies during the process. The highest loads, around $15 \mathrm{~N}$, occur on the storage reels. When the tape reaches the placement head the loads are very low, around $1.5 \mathrm{~N}$.

The fibres are still in bundles, there are few individual fibres visible. In the flax plate the fibres are organized in bundles and the extraction processes (scutching and hackling) divide them up but do not result in individual fibres. However, given the discontinuous nature of the fibres (10-100 mm environ), the fact that they are in bundles is an advantage, as it maintains cohesion between them and allows the fibres to be handled.

Figure 6 shows the microstructure of a biocomposite produced by AFP then compacted in a hot press. The structure is similar to that obtained in the reference material produced from 
ribbons directly by hot pressing (Figure 7), with a uniform distribution of the fibres and polymer due to the higher pressure applied (about 20 bars). The void content, determined by image analysis, (between $0.2 \%$ and 1\%) is much lower than after AFP alone, without consolidation (Figure 5).

The fibre volume fraction was determined by image analysis to be $41 \% \pm 2$ for AFP plates and $39 \% \pm 2$ for compression moulded reference plates.

\section{$\underline{3.3 \text { Comparison of mechanical properties for reference and AFP plates }}$}

Figures 8, 9 and 10 show typical recorded plots from longitudinal $\left(0^{\circ}\right)$ and transverse $\left(90^{\circ}\right)$ tension and in-plane shear tests for specimens produced by compression moulding and AFP+compression. The results for $0^{\circ}$ and $\pm 45^{\circ}$ composites are similar to published results for flax/epoxy composites $[31,32]$. The longitudinal tension stress-strain behaviour is not linear (Figure 8) [30,32]. For traditional unidirectional glass and carbon fibre reinforced thermoset composites tested in the fibre direction the mechanical response in tension is mainly influenced by the fibre behaviour and the stress-strain response is linear. For flax/PP there are additional factors which affect the behaviour:

- Flax fibres tested in tension show a non-linear stress-strain response. This is due to their microstructure, which is a multi-layer composite with oriented cellulose microfibrils in the cell walls. These can be aligned under tensile load and can also slide. When the fibres are in bundles internal sliding between them is also possible.

- The PP matrix shows highly non-linear behavior.

- Adhesion between flax fibres and unmodified PP is low.

- An additional damage mechanism, debonding of fibre outer layers, can also occur. 
There are generally two parts to the stress-strain curve and two moduli values can be determined (Table 1).

The transverse tensile behaviour here differs from that observed for flax/epoxy composites [31], with a ductile, non-linear stress-strain behaviour up to failure due to the ductile PP matrix. Once again the complex fibre structure and the non-linear matrix response will influence the composite response. Damage develops due to strain concentrations within fibre bundles, and moisture can also strongly affect transverse cohesion as it acts as a plasticizer. Residual thermal stresses may also play a role [34,35]

Table 1 shows the mechanical properties measured on the biocomposites produced by compression and by AFP + compression. The properties are very close, within experimental scatter, in spite of the additional thermo-mechanical cycle imposed by the AFP process. The longitudinal, transverse and shear properties depend on the fibres, matrix and fibre/matrix interfaces and the AFP process does not appear to affect any of these. In the absence of maleic anhydride, to improve the interface, the adherence of PP on the flax fibres is poor, which explains the low transverse tensile and shear strengths.

Comparisons with published results for natural fibre composites are always complicated as the mechanical properties of these fibres can vary, as they depend on the height of the plant stem from which the fibres are taken [36]. The best properties are obtained when fibres are extracted from the central region of the stem, but for the tests performed here there was no particular selection of fibres.

Figures 11 and 12 show a comparison of longitudinal tensile properties with published values for unidirectional flax/PP and flax/thermoset matrix composites. The modulus taken is the one corresponding to the initial slope, though this is not always specified in publications. 
Although PP has lower mechanical properties than the thermoset resins (mainly epoxy) the composite values are similar. The stiffness values (figure 11) obtained for the AFP composites are above the average while the strength values are lower (figure 12).

The mechanical properties in the longitudinal direction are strongly dependent on the fibre properties, the fibre volume fraction and the orientation. The presence of fibre bundles rather than separated fibres affects the properties, particularly the tensile strength [38]. It would be possible to improve this by selecting a reinforcement with more individual fibres.

For transverse tensile properties the modulus is low. This can be explained by the low transverse fibre strength, estimated to be around $8 \mathrm{GPa}$ [45], and the low stiffness of PP. Various factors may influence this value including the fibre content and distribution, internal stresses, and the fibre/matrix interface quality. With respect to the latter, PP does not adhere easily to flax fibres due to the low polarity of PP resulting in little interaction with the fibres $[33,46]$. Modifications to the matrix such as maleic anhydride grafting would enable this to be improved.

The low stiffness in shear is the result of the low shear moduli of the constituents. For flax fibres this has been estimated to be around $2.5 \mathrm{GPa}$ [47]. The shear stiffness of the composite is similar to published values, though few are available [48]. The fibre/matrix interface has a strong influence on this value and could be improved as noted above. For the materials tested here the cohesion of the fibre bundles also plays a role in off-axis properties.

Overall however, there is not a significant influence of the additional thermal cycle on composite properties.

\section{4- Conclusion}


The manufacture of a flax/PP semi-product by calendering of fibre layers with PP films has enabled composites to be laid up by a robot using tape placement (AFP). This semi-product is initially partially impregnated but has surface layers of PP which are beneficial to weld the tapes together. The porosity does not completely disappear during AFP processing and a subsequent consolidation step is required.

Flax fibres have limited temperature resistance, so the thermal cycling (time at temperature) has been minimized to avoid degradation. A reference material has been manufactured using the same semi-product but directly in a press. This reference material only undergoes two thermal cycles (calendering and pressing) compared to three for the AFP materials.

Comparison between the tensile and in-plane shear properties indicates that the additional thermal cycle does not affect composite properties.

Now that the tape production and manufacturing cycle have been established, trials will be performed on an improved matrix composition based on maleic anhydride modified PP, in order to improve fibre/matrix interface properties. Improved tape impregnation is also being studied, in order to eliminate the consolidation step after AFP.

This study has shown that it is possible to manufacture biocomposites using AFP, opening the way to producing complex components with these environmentally friendly materials.

\section{References}

[1] Ning H, Pillay S, Vaidya UK. Design and development of thermoplastic composite roof door for mass transit bus. Materials \& Design 2009;30:983-91. doi:10.1016/j.matdes.2008.06.066.

[2] Otheguy ME, Gibson AG, Findon E, Cripps RM, Mendoza AO, Castro MTA. Recycling of end-of-life thermoplastic composite boats. Plastics, Rubber and Composites 2009;38:406-11. doi:10.1179/146580109X12540995045642.

[3] Mihalich J. Production of a Class 8 Truck Trailer Bed Using c-PBT Thermoplastic Prepreg and Vacuum Bag Processing | Society of Plastics Engineers, Troy, Michigan, USA: Society of Plastics Engineers; 2010.

[4] Campbell FC. Chapter 10 : Thermoplastic Composites: An Unfulfilled Promise. In Manufacturing Processes For Advanced Composites, 2010, p. 517. 
[5] Friedrich K, Almajid AA. Manufacturing Aspects of Advanced Polymer Composites for Automotive Applications. Appl Comp Mater 2012;20:107-28. doi:10.1007/s10443-0129258-7.

[6] Campbell FC. Chapter 10 - Thermoplastic Composites: An Unfulfilled Promise. In: Campbell FC, editor. Manufacturing Processes for Advanced Composites, Amsterdam: Elsevier Science; 2004, p. 357-97.

[7] Nicolais L, Meo M, Milella E, editors. Composite Materials. London: Springer London; 2011.

[8] Beland S. High Performance Thermoplastic Resins and Their Composites. William Andrew; 2012.

[9] Wool RP. Self-healing materials: a review. Soft Matter 2008;4:400-18. doi:10.1039/B711716G.

[10] Pitchumani R, Gillespie JW, Lamontia MA. Design and Optimization of a Thermoplastic Tow-Placement Process with In-Situ Consolidation. Journal of Composite Materials 1997;31:244-75. doi:10.1177/002199839703100302.

[11] Le Duigou A, Davies P, Baley C. Environmental Impact Analysis of the Production of Flax Fibres to be Used as Composite Material Reinforcement. Journal of Biobased Materials and Bioenergy 2011;5:153-65. doi:10.1166/jbmb.2011.1116.

[12] Madsen B, Brøndsted P, Løgstrup Andersen T. Biobased composites: materials, properties and potential applications as wind turbine blade materials. In: Nijssen R, editor. Advances in wind turbine blade design and materials, Woodhead Publishing; 2013.

[13] Shah DU, Schubel PJ, Clifford MJ. Can flax replace E-glass in structural composites? A small wind turbine blade case study. Composites Part B: Engineering 2013;52:172-81. doi:10.1016/j.compositesb.2013.04.027.

[14] Bourmaud A, Baley C. Investigations on the recycling of hemp and sisal fibre reinforced polypropylene composites. Polymer Degradation and Stability 2007;92:1034-45. doi:10.1016/j.polymdegradstab.2007.02.018.

[15] Colin X, Verdu J. Polymer degradation during processing. Comptes Rendus Chimie 2006;9:1380-95. doi:10.1016/j.crci.2006.06.004.

[16] Yang L, Thomason JL, Zhu W. The influence of thermo-oxidative degradation on the measured interface strength of glass fibre-polypropylene. Composites Part A: Applied Science and Manufacturing 2011;42:1293-300. doi:10.1016/j.compositesa.2011.05.011.

[17] Lukaszewicz DH-JA, Ward C, Potter KD. The engineering aspects of automated prepreg layup: History, present and future. Composites Part B: Engineering 2012;43:997-1009. doi:10.1016/j.compositesb.2011.12.003.

[18] Lan M, Cartié D, Davies P, Baley C. Microstructure and tensile properties of carbonepoxy laminates produced by automated fibre placement: Influence of a caul plate on the effects of gap and overlap embedded defects. Composites Part A: Applied Science and Manufacturing 2015;78:124-34. doi:10.1016/j.compositesa.2015.07.023. 
[19] Wakeman MD, Cain TA, Rudd CD, Brooks R, Long AC. Compression moulding of glass and polypropylene composites for optimised macro- and micro- mechanical properties - 1 commingled glass and polypropylene. Composites Science and Technology 1998;58:1879-98. doi:10.1016/S0266-3538(98)00011-6.

[20] Tierney J, Gillespie JW. Modeling of Heat Transfer and Void Dynamics for the Thermoplastic Composite Tow-Placement Process. Journal of Composite Materials 2003;37:1745-68. doi:10.1177/002199803035188.

[21] Qureshi Z, Swait T, Scaife R, El-Dessouky HM. In situ consolidation of thermoplastic prepreg tape using automated tape placement technology: Potential and possibilities. Composites Part B: Engineering 2014;66:255-67. doi:10.1016/j.compositesb.2014.05.025.

[22] Comer AJ, Ray D, Obande WO, Jones D, Lyons J, Rosca I, et al. Mechanical characterisation of carbon fibre-PEEK manufactured by laser-assisted automated-tapeplacement and autoclave. Composites Part A: Applied Science and Manufacturing 2015;69:10-20. doi:10.1016/j.compositesa.2014.10.003.

[23] August Z, Ostrander G, Michasiow J, Hauber D. Recent Developments in Automated Fiber Placement of Thermoplastic. Composites SAMPE Journal 2014;50:30-7.

[24] Gorshkova T, Morvan C. Secondary cell-wall assembly in flax phloem fibres: role of galactans. Planta 2006;223:149-58. doi:10.1007/s00425-005-0118-7.

[25] Gassan J, Bledzki AK. Thermal degradation of flax and jute fibers. J Appl Polym Sci 2001;82:1417-22. doi:10.1002/app.1979.

[26] Gourier C, Le Duigou A, Bourmaud A, Baley C. Mechanical analysis of elementary flax fibre tensile properties after different thermal cycles. Composites Part A: Applied Science and Manufacturing 2014;64:159-66. doi:10.1016/j.compositesa.2014.05.006.

[27] Doumbia AS, Castro M, Jouannet D, Kervoëlen A, Falher T, Cauret L, et al. Flax/polypropylene composites for lightened structures: Multiscale analysis of process and fibre parameters. Materials \& Design 2015;87:331-41. doi:10.1016/j.matdes.2015.07.139.

[28] Duc AL. Comportement et rupture de fibres cellulosiques lors de leur compoundage avec une matrice polymère. Thesis report. Ecole Nationale Supérieure des Mines de Paris, 2013.

[29] Moothoo J, Allaoui S, Ouagne P, Soulat D. A study of the tensile behaviour of flax tows and their potential for composite processing. Materials \& Design 2014;55:764-72. doi:10.1016/j.matdes.2013.10.048.

[30] Baets J, Plastria D, Ivens J, Verpoest I. Determination of the optimal flax fibre preparation for use in unidirectional flax-epoxy composites. Journal of Reinforced Plastics and Composites 2014:0731684413518620. doi:10.1177/0731684413518620.

[31] Liang S, Gning P-B, Guillaumat L. Quasi-static behaviour and damage assessment of flax/epoxy composites. Materials \& Design 2015;67:344-53. doi:10.1016/j.matdes.2014.11.048. 
[32] Andersons J, Modniks J, Spārniņš E. Modeling the nonlinear deformation of flax-fiberreinforced polymer matrix laminates in active loading. Journal of Reinforced Plastics and Composites 2015;34:248-56. doi:10.1177/0731684414568043.

[33] Graupner N, Rößler J, Ziegmann G, Müssig J. Fibre/matrix adhesion of cellulose fibres in PLA, PP and MAPP: A critical review of pull-out test, microbond test and single fibre fragmentation test results. Composites Part A: Applied Science and Manufacturing 2014;63:133-48. doi:10.1016/j.compositesa.2014.04.011.

[34] Nairn JA. Thermoelastic analysis of residual stresses in unidirectional, high-performance composites. Polymer Composites 1985;6:123-30. doi:10.1002/pc.750060211.

[35] Yang L, Thomason JL. Interface strength in glass fibre-polypropylene measured using the fibre pull-out and microbond methods. Composites Part A: 2010;41:1077-83.

[36] Martin N, Davies P, Baley C. Comparison of the properties of scutched flax and flax tow for composite material reinforcement. Industrial Crops and Products 2014;61:284-92. doi:10.1016/j.indcrop.2014.07.015.

[37] Van de Weyenberg I, Ivens J, De Coster A, Kino B, Baetens E, Verpoest I. Influence of processing and chemical treatment of flax fibres on their composites. Composites Science and Technology 2003;63:1241-6. doi:10.1016/S0266-3538(03)00093-9.

[38] Coroller G, Lefeuvre A, Le Duigou A, Bourmaud A, Ausias G, Gaudry T, et al. Effect of flax fibres individualisation on tensile failure of flax/epoxy unidirectional composite. Composites Part A: Applied Science and Manufacturing 2013;51:62-70. doi:10.1016/j.compositesa.2013.03.018.

[39] Poilâne C, Cherif ZE, Richard F, Vivet A, Ben Doudou B, Chen J. Polymer reinforced by flax fibres as a viscoelastoplastic material. Composite Structures 2014;112:100-12. doi:10.1016/j.compstruct.2014.01.043.

[40] Liang S, Gning P-B, Guillaumat L. Properties evolution of flax/epoxy composites under fatigue loading. International Journal of Fatigue 2014;63:36-45. doi:10.1016/j.ijfatigue.2014.01.003.

[41] Oksman K. High Quality Flax Fibre Composites Manufactured by the Resin Transfer Moulding Process. Journal of Reinforced Plastics and Composites 2001;20:621-7. doi:10.1177/073168401772678634.

[42] Baley C, Le Duigou A, Bourmaud A, Davies P. Influence of drying on the mechanical behaviour of flax fibres and their unidirectional composites. Composites Part A: Applied Science and Manufacturing 2012;43:1226-33. doi:10.1016/j.compositesa.2012.03.005.

[43] Hughes M, Carpenter J, Hill C. Deformation and fracture behaviour of flax fibre reinforced thermosetting polymer matrix composites. J Mater Sci 2007;42:2499-511. doi:10.1007/s10853-006-1027-2.

[44] Madsen B, Lilholt H. Physical and mechanical properties of unidirectional plant fibre composites - an evaluation of the influence of porosity. Composites Science and Technology 2003;63:1265-72. doi:10.1016/S0266-3538(03)00097-6. 
[45] Baley C, Perrot Y, Busnel F, Guezenoc H, Davies P. Transverse tensile behaviour of unidirectional plies reinforced with flax fibres. Materials Letters 2006;60:2984-7. doi:10.1016/j.matlet.2006.02.028.

[46] Awal A, Cescutti G, Ghosh SB, Müssig J. Interfacial studies of natural fibre/polypropylene composites using single fibre fragmentation test (SFFT). Composites Part A: Applied Science and Manufacturing 2011;42:50-6. doi:10.1016/j.compositesa.2010.10.007.

[47] Charlet K, Eve S, Jernot JP, Gomina M, Breard J. Tensile deformation of a flax fiber. Procedia Engineering 2009;1:233-6. doi:10.1016/j.proeng.2009.06.055.

[48] Gning PB, Liang S, Guillaumat L, Pui WJ. Influence of process and test parameters on the mechanical properties of flax/epoxy composites using response surface methodology. J Mater Sci 2011;46:6801-11. doi:10.1007/s10853-011-5639-9. 
Figure 1: Microstructure of a flax/PP tape section, from an unsuccessful extrusion trial.

Note the presence of fibres on the tape surface, which will burn during laser heating.

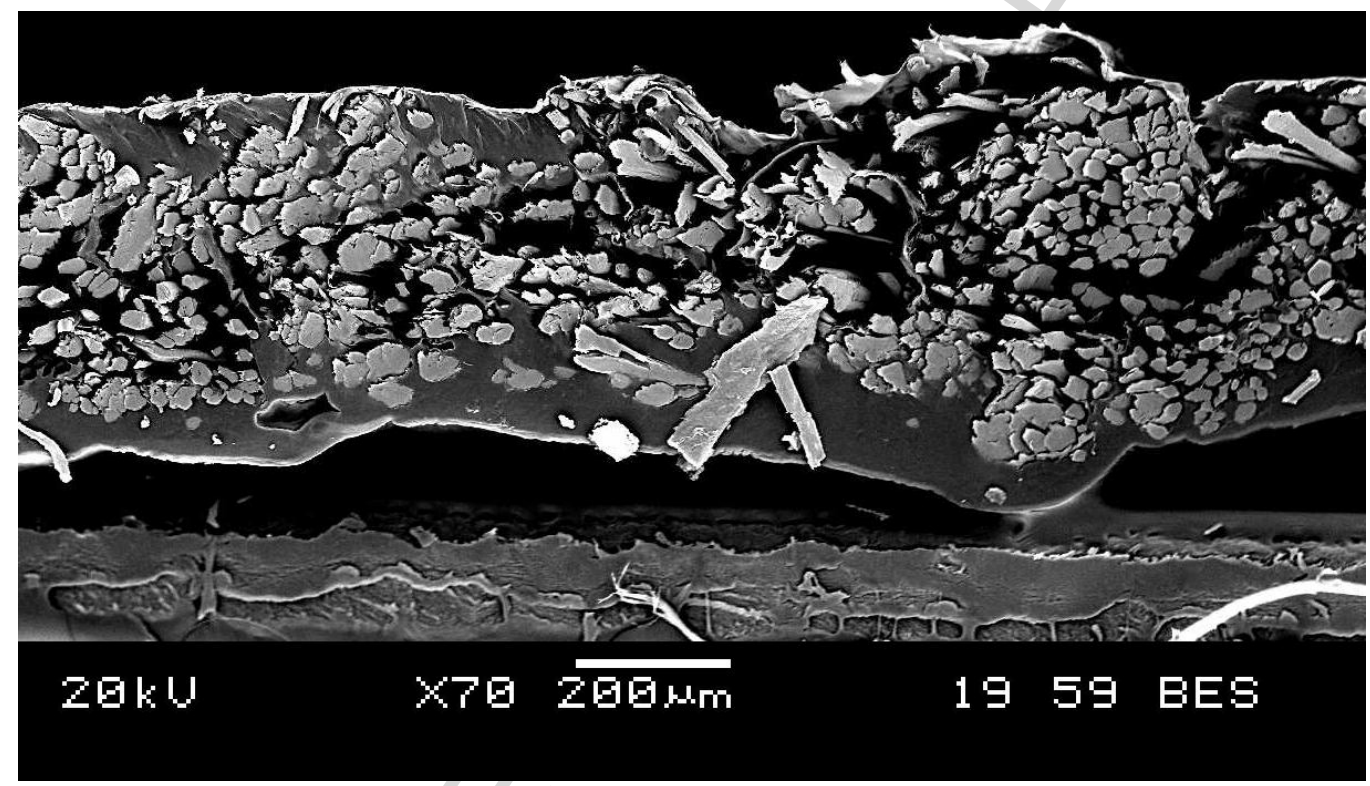


Figure 2: Schematic of tape lay-down process

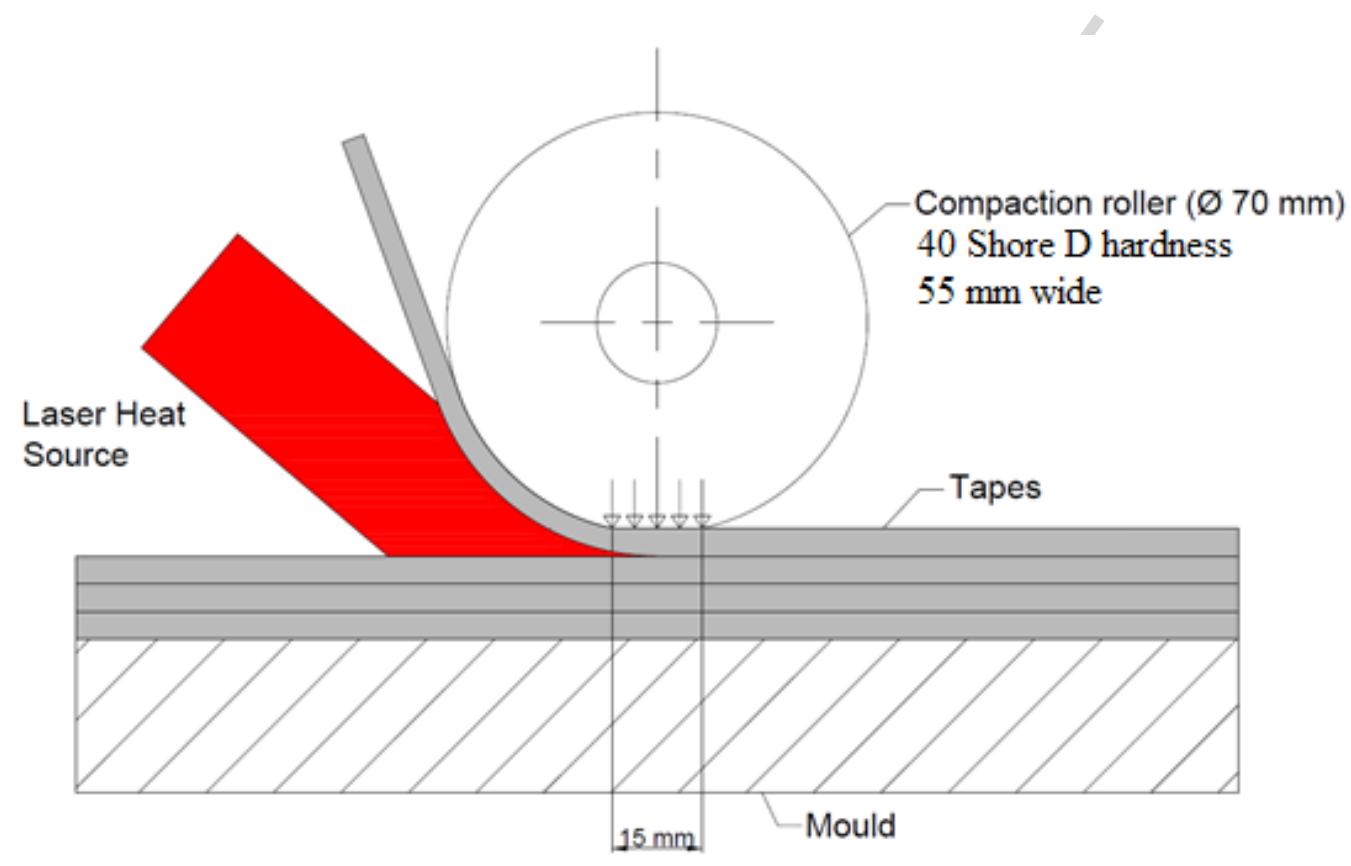


Figure 3: Specimen with $\pm 45^{\circ}$ reinforcement produced by AFP. The tape width is $6.35 \mathrm{~mm}$.

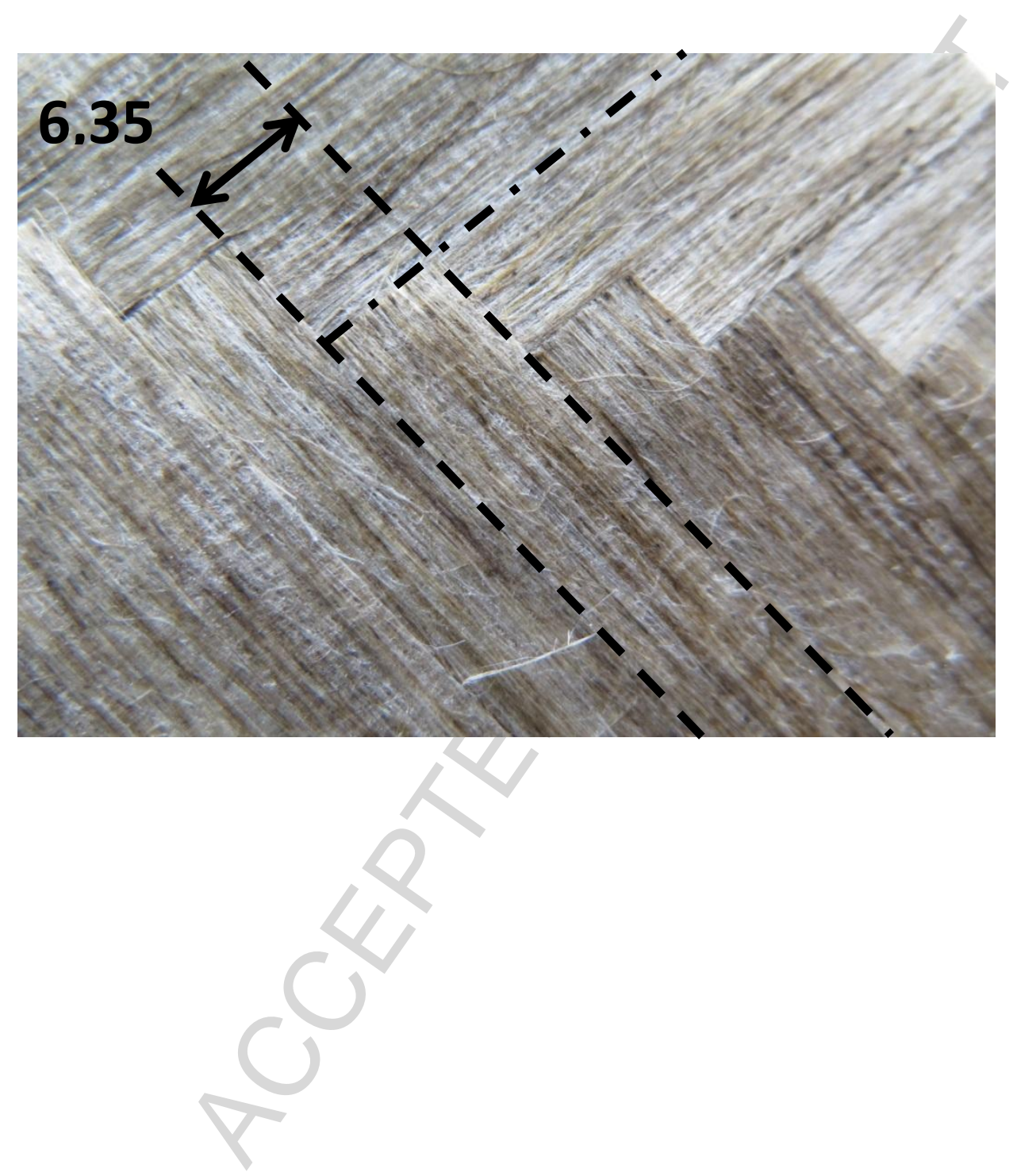


Figure 4: cross-section of a calendered band of preimpregnated flax/PP

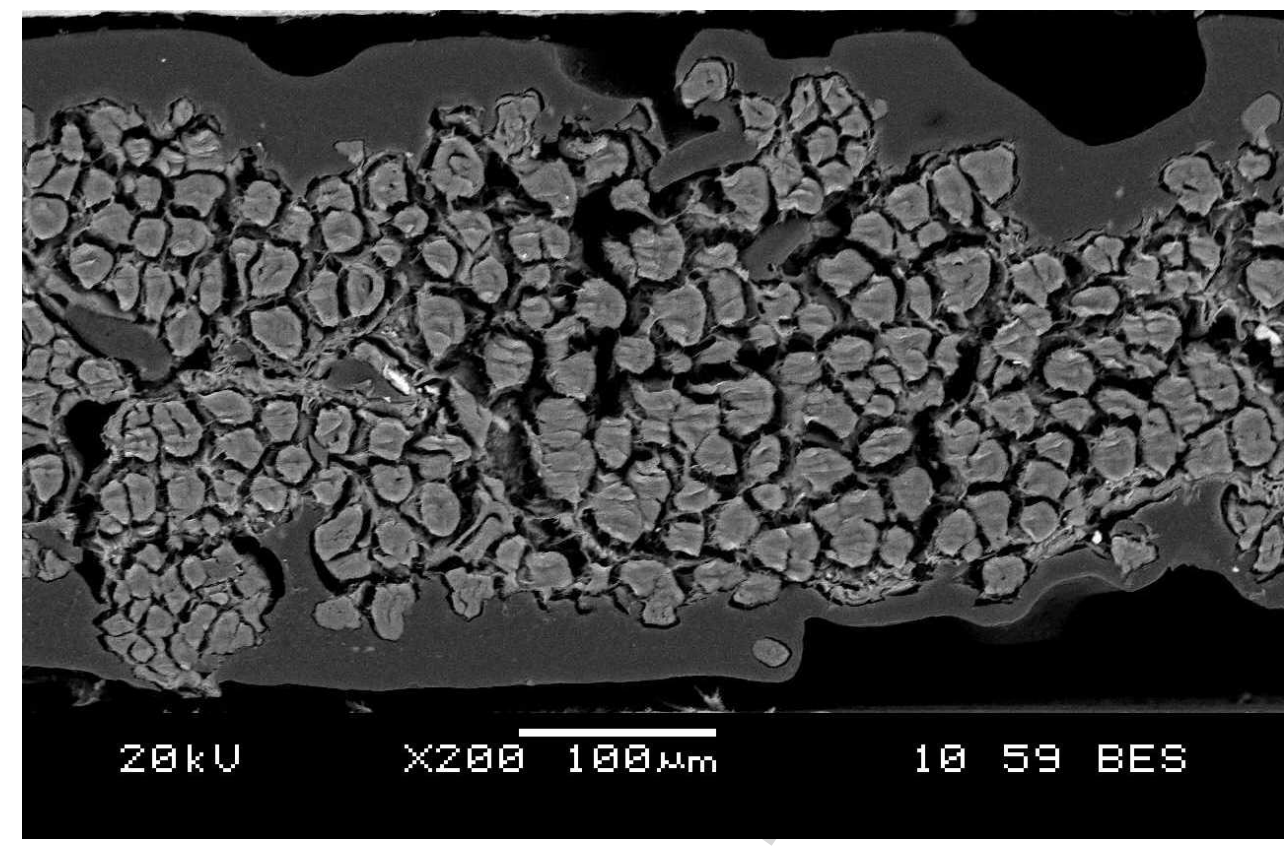


Figure 5: Microstructure of a 10-ply stack after AFP.

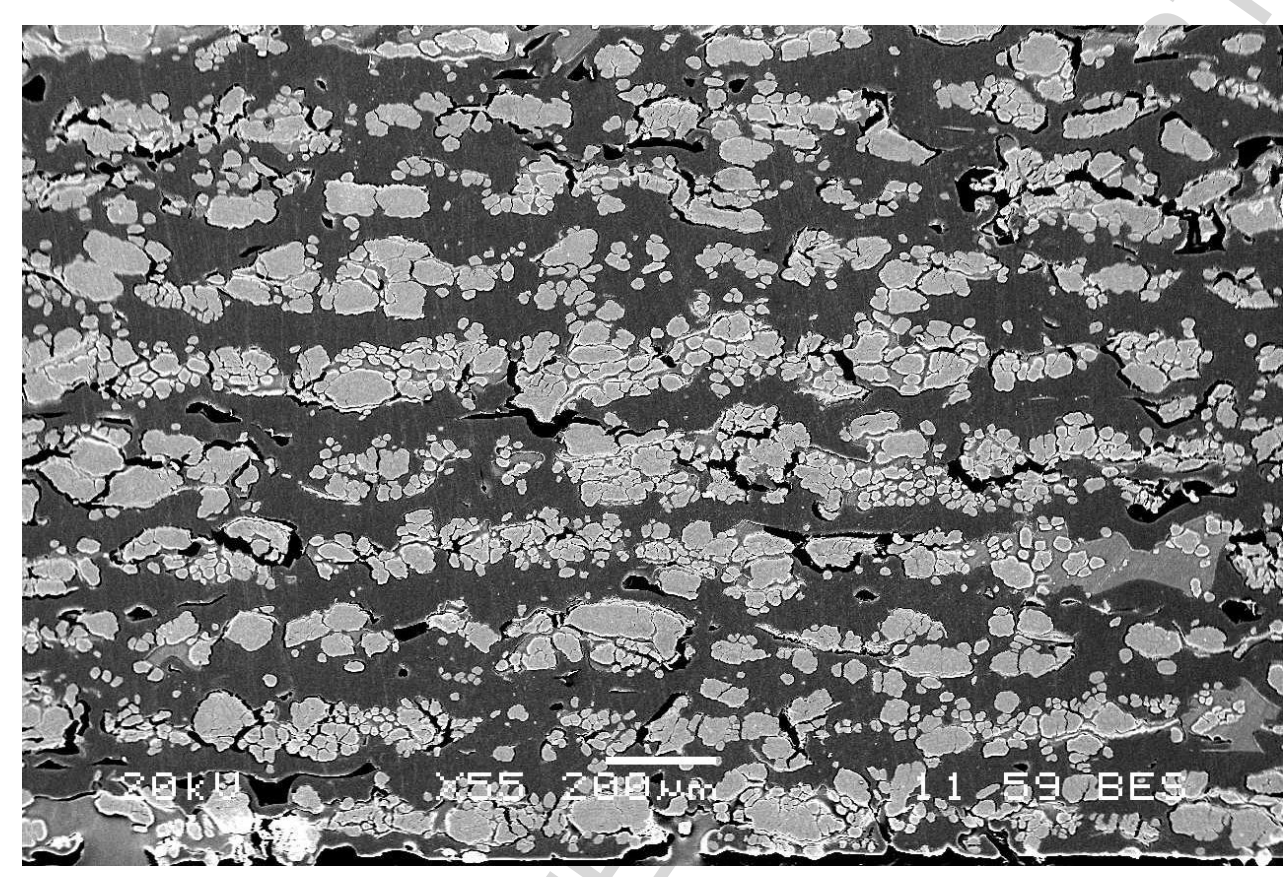


Figure 6: Microstructure of plate produced by AFP then compression moulding.

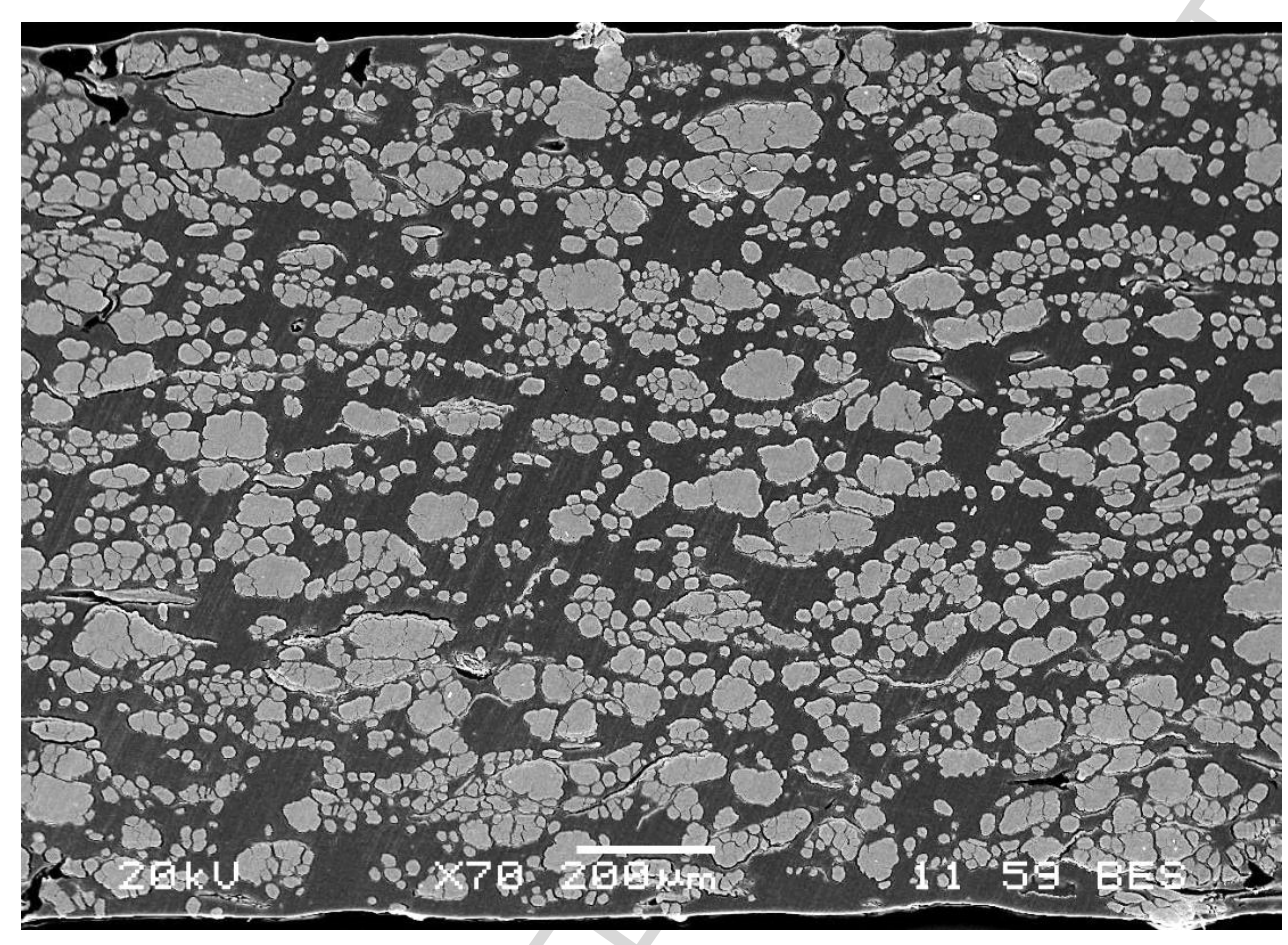


Figure 7: Microstructure of reference plate produced by compression moulding.

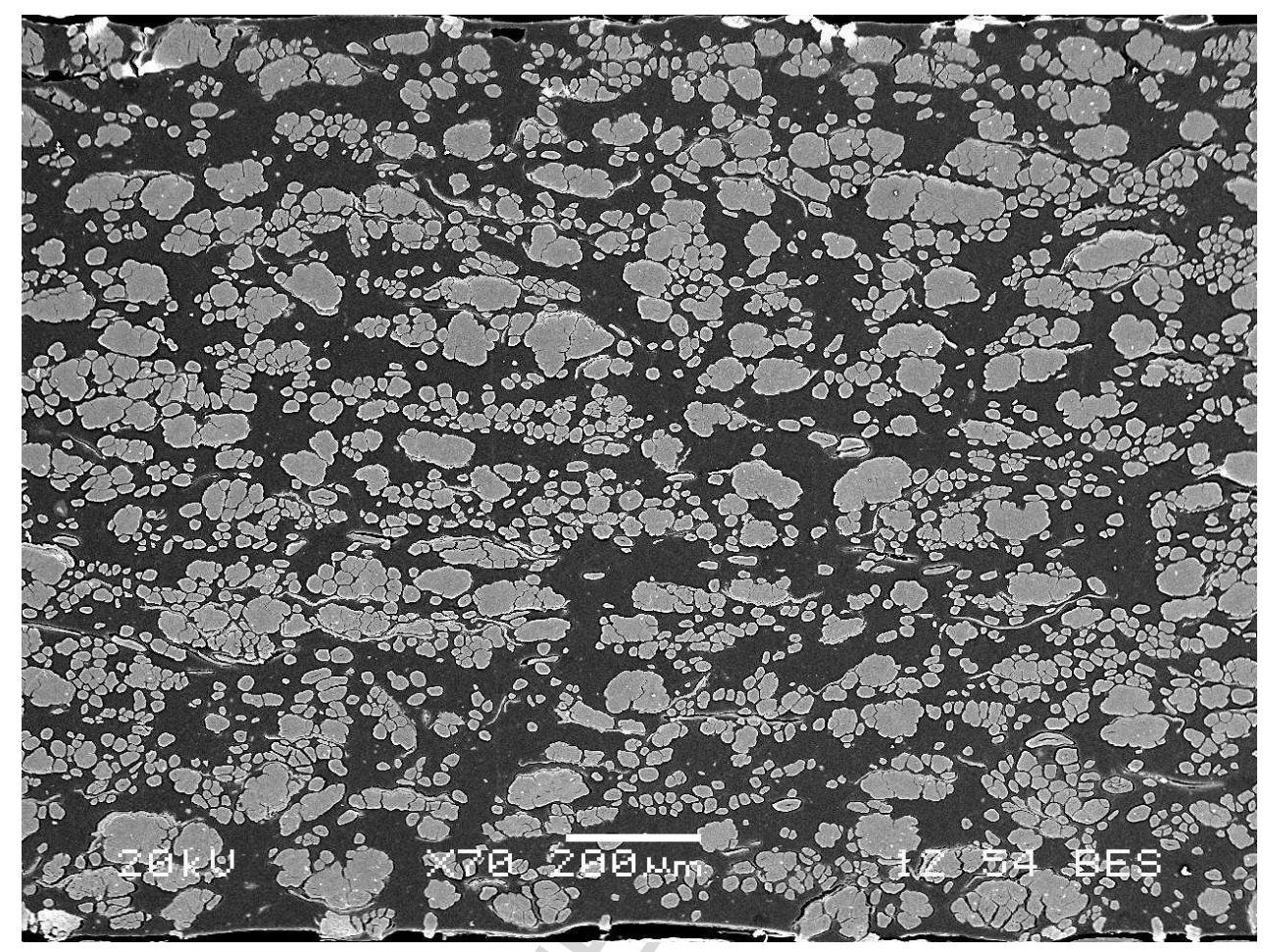


Figure 8: Stress-strain plots for longitudinal tension

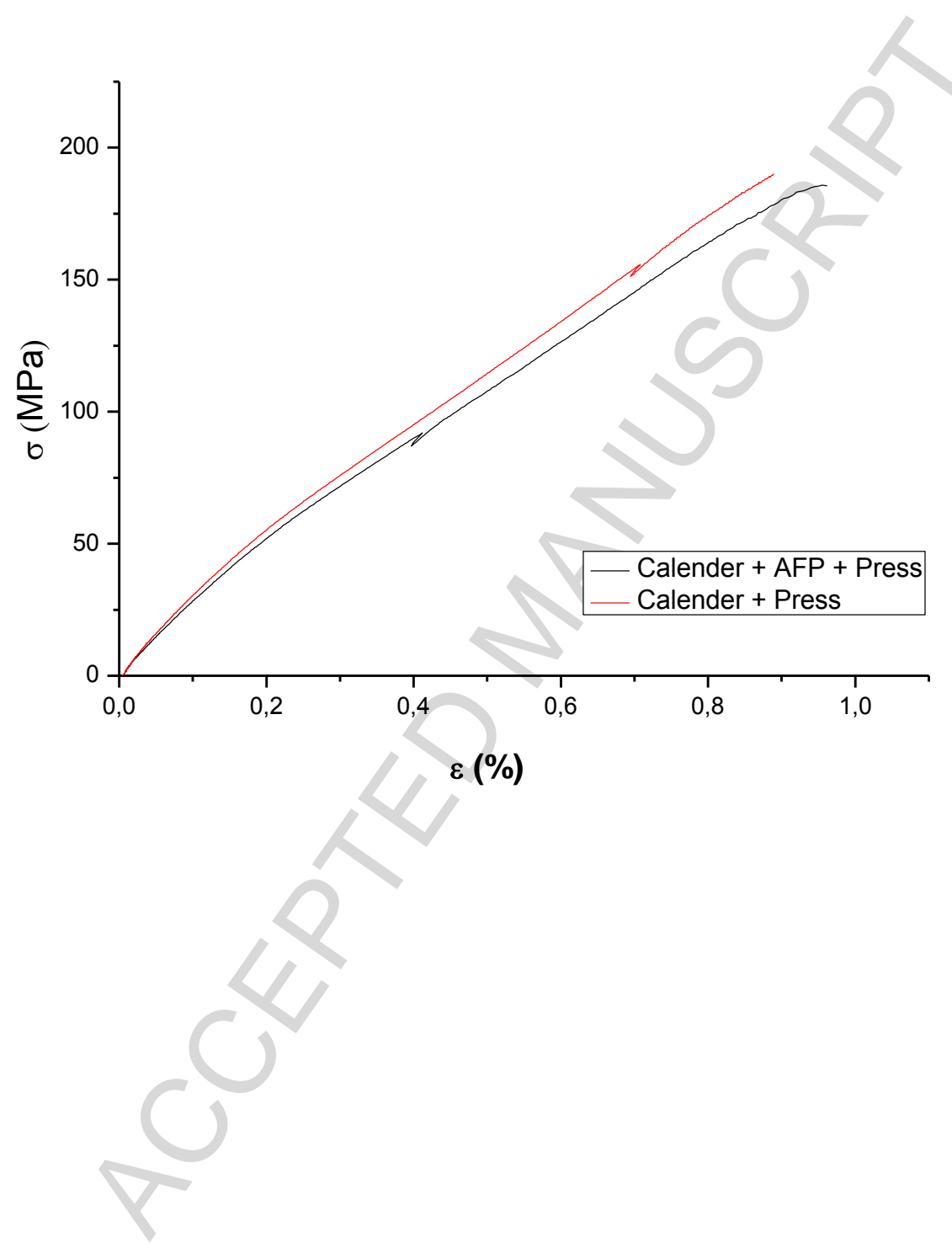


Figure 9: Stress-strain plots for transverse tension

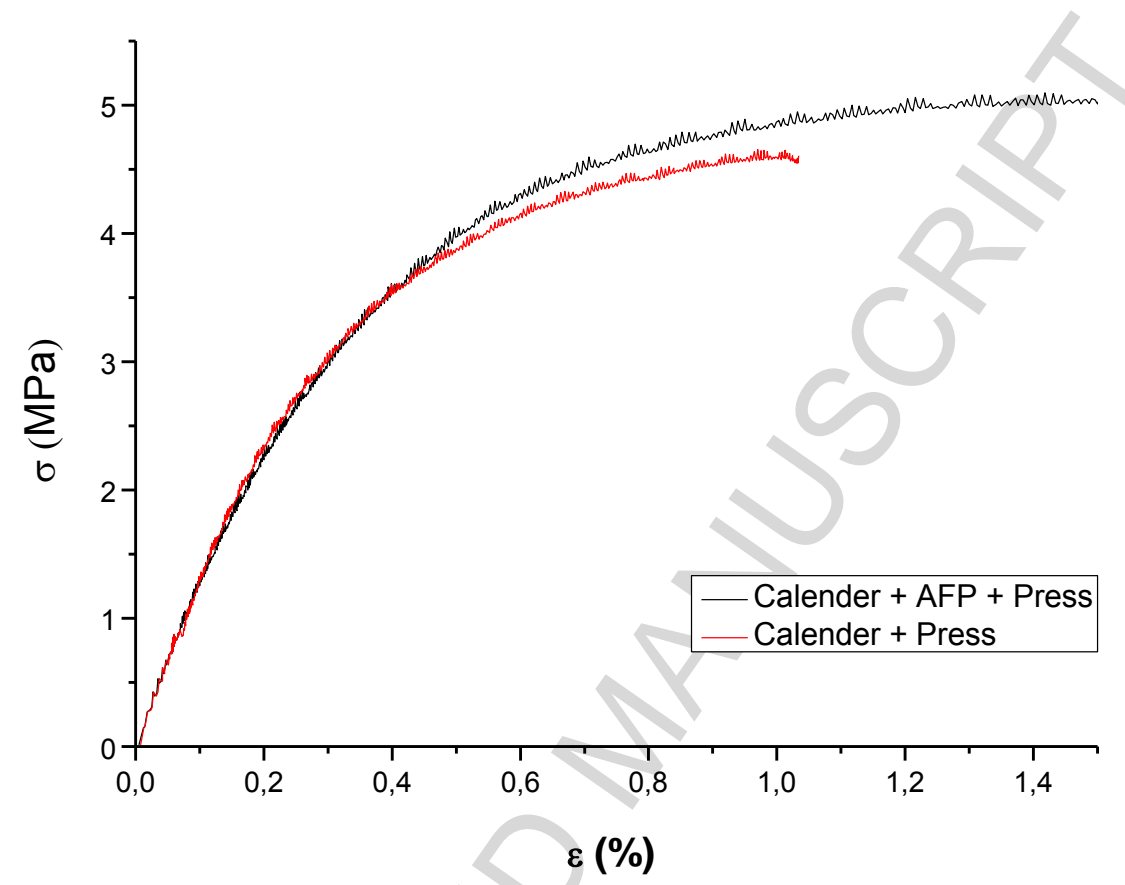


Figure 10: Stress-strain plots for tension tests on $\pm 45^{\circ}$ laminates.

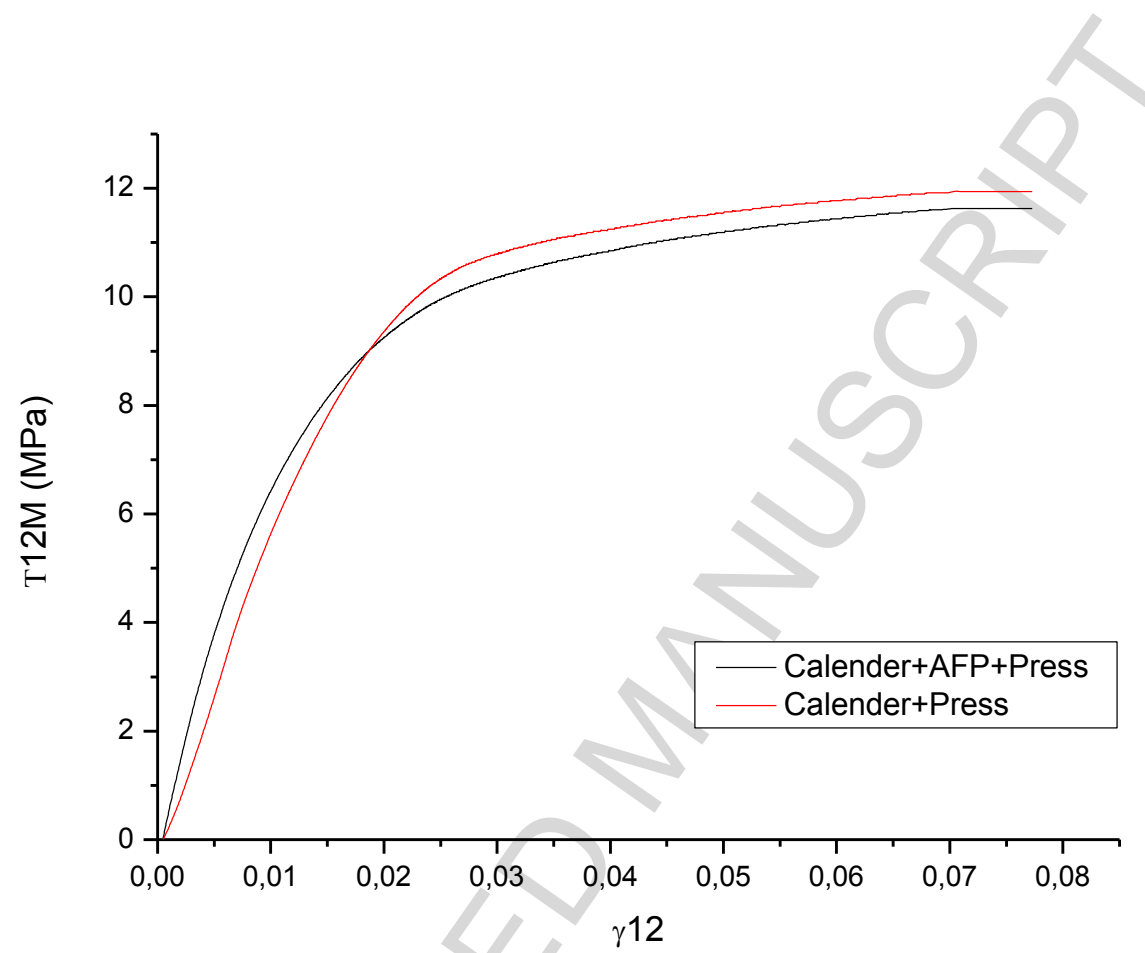


Figure 11 : Longitudinal tensile modulus values measured here compared to published values for unidirectional flax/thermoset composites [33], [34], [35], [36], [37], [38], [39], [28], [40] and flax/PP [41].

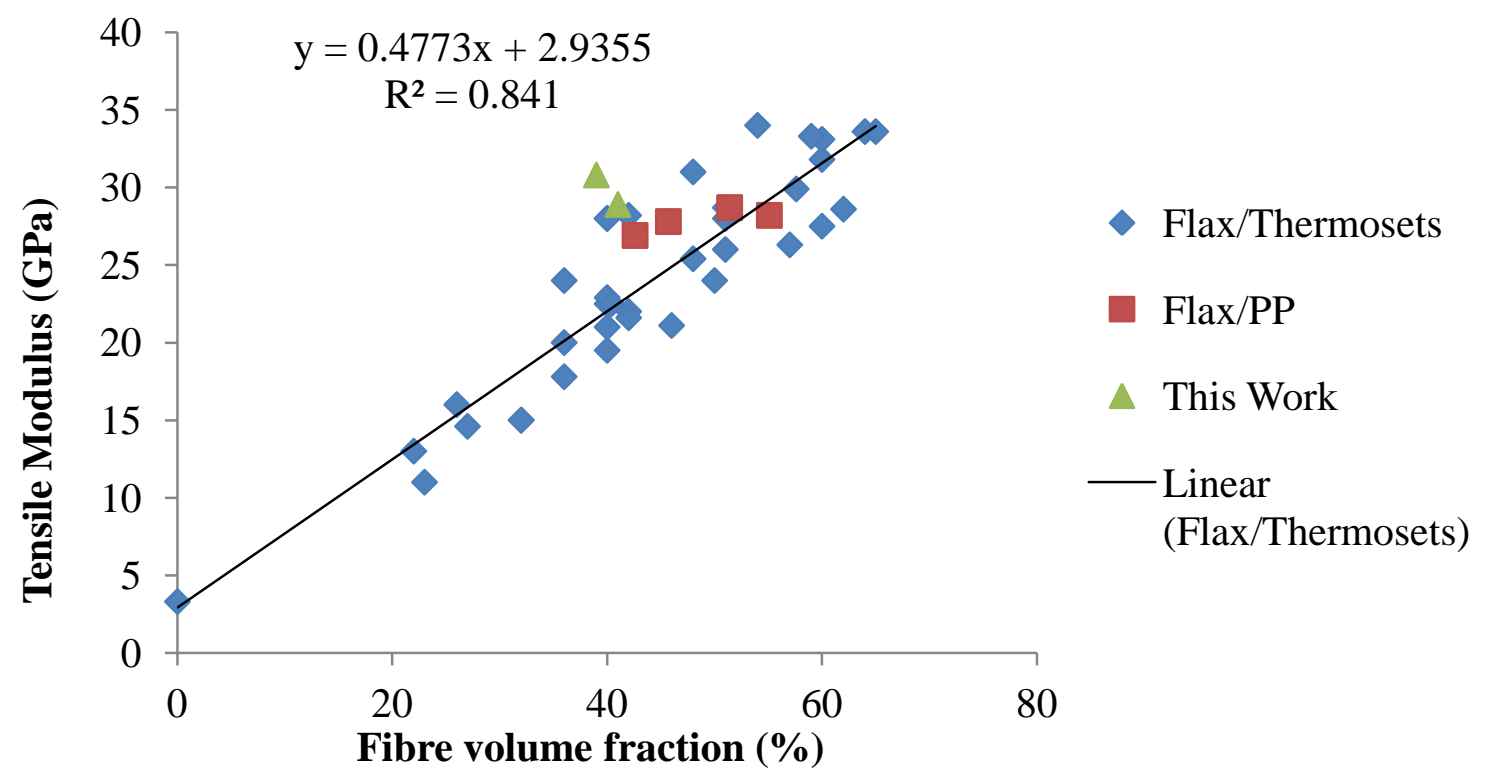


Figure 12 : Longitudinal tensile strength values measured here compared to published values for unidirectional flax/thermoset composites [33], [34], [35], [36], [37], [38], [39], [28], [40] and flax/PP [41].

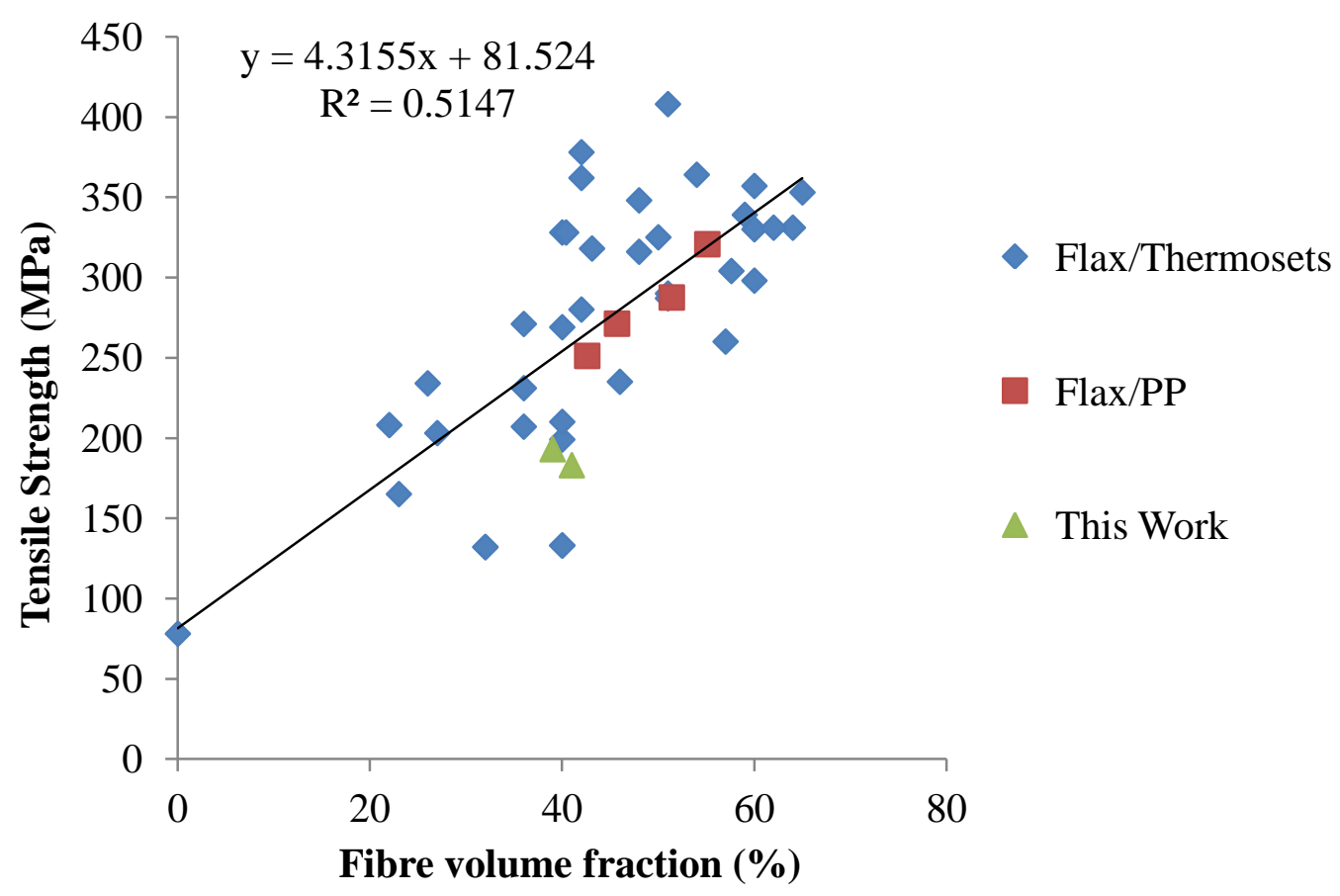


Table 1: Mechanical properties of biocomposites produced by two manufacturing cycles

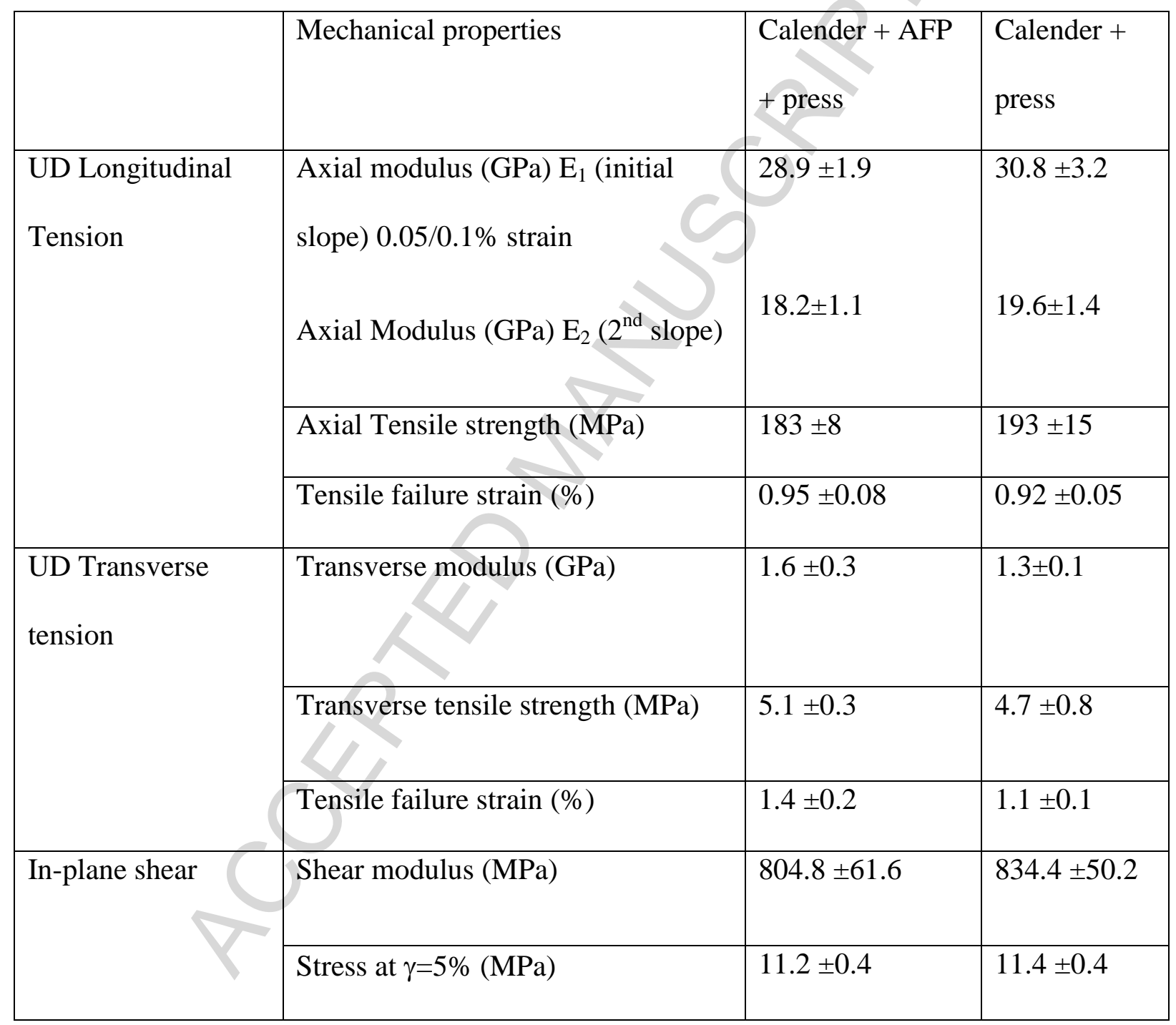

